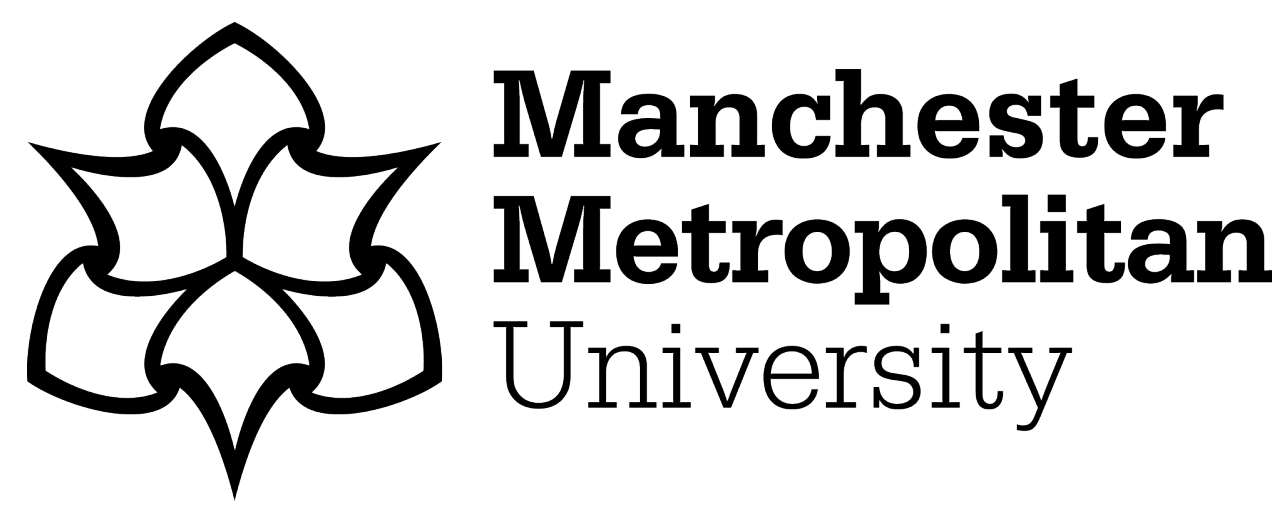

Kiener, J, Tosheva, L and Parmentier, J (2017) Carbide, nitride and sulfide transition metal-based macrospheres. Journal of the European Ceramic Society, 37 (3). pp. 1127-1130. ISSN 0955-2219

Downloaded from: https://e-space.mmu.ac.uk/617304/

Version: Accepted Version

Publisher: Elsevier

DOI: https://doi.org/10.1016/j.jeurceramsoc.2016.10.012

Please cite the published version 


\section{Carbide, nitride and sulfide transition metal-based macrospheres}

Julien Kiener ${ }^{a}$, Lubomira Tosheva ${ }^{b, *}$, Julien Parmentier ${ }^{\text {a,* }}$

${ }^{a}$ Université de Haute-Alsace, Institut de Science des Matériaux de Mulhouse - IS2M UMR CNRS 7361, 15 rue Jean Starcky - BP 2488- 68057 Mulhouse Cedex, France

${ }^{b}$ Division of Chemistry and Environmental Science, Manchester Metropolitan

University, Chester St., Manchester, M1 5GD, UK

A general method for the preparation of transition metal carbide, nitride and sulfide composite materials in the form of macroscopic beads is reported. Ti- and W-based materials were prepared by thermal conversion of Ti- or W-loaded ion-exchange resins in an appropriate atmosphere, inert, $\mathrm{NH}_{3}$ or $\mathrm{H}_{2} \mathrm{~S}$, respectively. The spherical macroscopic shape of the resin was preserved in most of the product composite materials. The fabrication of pure TiN spherical macrostructures is also demonstrated by using $\mathrm{TiO}_{2}$ spherical beads prepared from the Ti-loaded resin by resin oxidation at 600 ${ }^{\circ} \mathrm{C}$ in the thermal treatment procedure.

Keywords: Resin templating; Macroscopic beads, Transition metal carbides, Transition metal nitrides, Transition metal sulfides

\footnotetext{
* Corresponding author. Tel.: +44 161 2471426; fax: +44 1612476840.

E-mail address: 1.tosheva@mmu.ac.uk (L. Tosheva)
} 


\section{Introduction}

Powders are used in many industrial-scale processes but difficulties related to their pulverulent nature often arise during transport, handling, storage and operation, for instance arching and rate-holing in hoppers, pressure-drop in reactors; sanitary problems with dust, attrition with containers, etc. On many occasions, these problems can be minimised without using costly specialised equipment by replacement with granular materials such as macroscopic beads (i.e. beads with sizes exceeding $0.1 \mathrm{~mm}$ ). Porous macroscopic beads are of particular importance for sorption and catalytic applications in fixed bed reactors due to their reduced pressure-drop limitations. The resin templating method, which involves the use of ion-exchange resins for the production of porous macroscopic beads, has been employed to prepare a variety of inorganic structures. The use of resin beads as templates has several advantages: (i) resins are commercially available in a variety of bead sizes; (ii) they are available as macroreticular or gel resins (with or without the presence of a permanent network of pores, respectively), providing control over the porous structure of the inorganic composites or replicas; (iii) cationand anion-exchange resins are available, making it possible to use a vast number of precursor solutions; and (iv) their organic nature allows for their carbonisation in inert atmosphere or complete combustion. We have used the resin templating method to prepare zeolitic, ${ }^{1}$ silica, ${ }^{2}$ carbon replicas of zeolites ${ }^{3}$ and carbon and $\mathrm{SiC}$ beads. ${ }^{4}$ The resin templating method has been used by others to prepare porous macroscopic beads of cerium oxide ${ }^{5,6}$ and gadolinium-doped ceria, ${ }^{7} \mathrm{Fe}_{2} \mathrm{O}_{3}, \mathrm{Al}_{2} \mathrm{O}_{3}$ and $\mathrm{TiO}_{2},{ }^{8} \mathrm{ZrO}_{2},{ }^{9}$ $\mathrm{ZrO}_{2} / \mathrm{Al}_{2} \mathrm{O}_{3},{ }^{10} \mathrm{TiO}_{2},{ }^{11,12}$ and $\mathrm{TiO}_{2}-\mathrm{SiO}_{2} .{ }^{13}$ The organic nature of the ion-exchange resins has been explored to prepare various metal-supported catalysts on carbonised resin beads such as $\mathrm{Pt}, \mathrm{V}$ and $\mathrm{Cu} / \mathrm{ZnO}$ and $\mathrm{Ni}^{14-17}$ 
In order to take advantage of the interesting properties of porous macroscopic beads for existing or new potential applications, there are needs to develop further the range of compositions available by resin templating, especially for non-oxide transition metals (TM). Non-oxide TM such as nitrides, carbides and sulfides are of interest for applications in energy storage, solar cells and catalysis. ${ }^{18,19}$ Tungsten carbide has shown potential as a replacement of noble-metal catalysts in the degradation of cellulose. ${ }^{20}$ Moreover, TM carbides and nitrides are well-known as hard and wear resistant materials. ${ }^{21} \mathrm{TM}$ carbides, nitrides and sulfides display interesting low friction coefficients with refractory properties. Since TM non-oxide macroscopic beads are rarely reported in the literature, the aim of this study is to demonstrate the possibility to use ion-exchange resins as precursors for such materials. Ti- and W-loaded ionexchange resins were used as precursor materials in this study.

\section{Experimental procedures}

A strongly basic anion-exchange resin (Amberlite IRA-900, Aldrich) was used in all experiments. Ti- and $\mathrm{W}$-loaded resin composites were prepared by ion-exchange from Ti- and W-precursor solutions. The titanium precursor solution was prepared by adding Titanium (IV) isopropoxide (Ti-iso, 95\%, Alfa Aesar) to Propan-2-ol (PrOH, HPLC grade, Fisher Scientific; dried over 4A molecular sieve prior to use) and mixing for 15 min. 1 wt.\% aqueous tetra-n-propyl ammonium hydroxide solution (TPAOH, 1M aqueous solution, Alfa Aesar) was then added dropwise to the clear mixture, which resulted in the formation of a gel, and stirring continued for $1 \mathrm{~h}$. The molar composition of the Ti precursor mixture was $1.0 \mathrm{Ti}$-iso : 9.5PrOH: $0.2 \mathrm{TPAOH}: 218.9 \mathrm{H}_{2} \mathrm{O}$. The ionexchange resin was converted to a hydroxide form by soaking in $1 \mathrm{M}$ sodium hydroxide 
solution and repeated rinsing with distilled water prior to adding to the Ti precursor mixture at a weight ratio of 1 to 10 in a polypropylene reactor. The mixture was treated at $95{ }^{\circ} \mathrm{C}$ for $24 \mathrm{~h}$. After the synthesis, the mother liquor was decanted and the Ti/resin composite was washed with distilled water and dried at $70{ }^{\circ} \mathrm{C}$ overnight. A single batch of $\mathrm{Ti} /$ resin composite was used in all further experiments. Ti/resin beads were heattreated directly in the appropriate gaseous atmosphere at different temperature: at 900 ${ }^{\circ} \mathrm{C}$ for 3 hours in $\mathrm{NH}_{3}$ flow $\left(4 \mathrm{~L} \mathrm{~h}^{-1}\right)$, at $1000{ }^{\circ} \mathrm{C}$ for 12 hours and at $1100{ }^{\circ} \mathrm{C}$ for 6 hours in $\mathrm{Ar}$ flow $\left(8 \mathrm{~L} \mathrm{~h}^{-1}\right)$ to obtain $\mathrm{TiN} / \mathrm{C}, \mathrm{TiC} / \mathrm{C}-1000{ }^{\circ} \mathrm{C}$ and $\mathrm{TiC} / \mathrm{C}-1100{ }^{\circ} \mathrm{C}$ samples, respectively. For heat-treatments of all samples, the heating ramps used were done in $\mathrm{Ar}$ at a rate of $1{ }^{\circ} \mathrm{C} \mathrm{min}-1$ from room temperature to $600{ }^{\circ} \mathrm{C}$ and $5{ }^{\circ} \mathrm{C} \mathrm{min}-1$ from $600{ }^{\circ} \mathrm{C}$ to the final temperature.

To explore a two-step route, namely nitridation of oxide macrospheres instead of direct nitridation of $\mathrm{TM} /$ resin composite, $\mathrm{TiO}_{2}$ macrospheres were also obtained by calcination of the above Ti/resin composite in air at $600{ }^{\circ} \mathrm{C}$ for $10 \mathrm{~h}$ (heating rate of 5 $\left.{ }^{\circ} \mathrm{C} \min ^{-1}\right)$. These macrostructures were then treated at $900{ }^{\circ} \mathrm{C}$ for 3 hours under $\mathrm{NH}_{3}$ flow $\left(4 \mathrm{~L} \mathrm{~h}^{-1}\right)$ to obtain TiN-900 ${ }^{\circ} \mathrm{C}$.

The $\mathrm{W} /$ resin composite was prepared by adding as received resin to $0.01 \mathrm{M}$ sodium tungstate dihydrate solution $\left(\mathrm{Na}_{2} \mathrm{WO}_{4} \cdot 2 \mathrm{H}_{2} \mathrm{O}\right.$, Sigma Aldrich) at a weight ratio of 1 to 10 in a beaker. The beaker was covered with parafilm and kept at room temperature for 7 days. After the treatment, the solution was decanted and the W/resin composite was washed with distilled water. Finally, the composite was dried at $70{ }^{\circ} \mathrm{C}$ overnight. W/resin beads were heated at $900{ }^{\circ} \mathrm{C}$ for three hours in $\mathrm{NH}_{3}$ flow to obtain WN/C-900 ${ }^{\circ} \mathrm{C}$ sample, at $950{ }^{\circ} \mathrm{C}$ for 12 hours in Ar flow to obtain WC/C-950 ${ }^{\circ} \mathrm{C}$ 
sample, and at $950{ }^{\circ} \mathrm{C}$ for 3 hours in $\mathrm{H}_{2} \mathrm{~S}\left(1.2 \mathrm{~L} \mathrm{~h}^{-1}\right.$ flow $)$ to obtain $\mathrm{WS}_{2} / \mathrm{C}-950^{\circ} \mathrm{C}$ sample.

X-Ray Diffraction (XRD) patterns were obtained by transmission through a capillary silica tube on a STOE Diffractometer, STADI-P model with $\mathrm{Cu}$ Ka radiation (1.54 $\AA$ ). Ti-based macrospheres were crushed and inserted in the capillary tube whereas W-based macrospheres could not be manually crushed (because of their mechanical toughness and spherical shape) and were introduced as made in the capillary. Scanning Electron Microscope Philips, XL30 was used to obtain micrographs of beads without gold sputtering.

Thermogravimetric analysis were obtained on a thermogravimetric analyser Mettler-Toledo TGA/DSC 3+. Samples were heated at $600{ }^{\circ} \mathrm{C}$ under argon flow with a $5^{\circ} \mathrm{C} / \mathrm{min}$ heating ramp. At $600^{\circ} \mathrm{C}$, argon flow was switched for air flow and temperature was maintained at $600^{\circ} \mathrm{C}$ during one hour.

\section{Results and Discussion}

To exemplify the formation of non-oxide TM beads from ion-exchange resins, we firstly prepared $\mathrm{Ti} /$ resin and $\mathrm{W} /$ resin composites by ion exchange from $\mathrm{Ti}$ - and $\mathrm{W}$ precursor solutions. The conversion of the composites was then realised by either gas/solid reactions performed with $\mathrm{NH}_{3}$ or $\mathrm{H}_{2} \mathrm{~S}$ gas to yield metal nitrides and metal sulfides, respectively, or by solid/solid reaction between TM oxide and carbon arising from the carbonised resin for the formation of metal carbides. Fig. 1 illustrates schematically the process used to prepare MX macroscopic beads upon resin carbonisation $(\mathrm{M}=\mathrm{TM}(\mathrm{Ti}$ or $\mathrm{W}), \mathrm{X}=\mathrm{C}, \mathrm{N}$ or $\mathrm{S})$. 
SEM images of Ti/resin and W/resin composites showed spherical macroscopic beads with an average diameter of $0.5 \mathrm{~mm}$, which were similar in size and shape to the original resin beads (Fig. S1, Supplementary Information). SEM micrographs of the Tibased/C and $\mathrm{W}$-based/C beads obtained after heat-treatment in the respective atmosphere and carbonisation of the resin are shown in Fig. 2. Except for the WN/C$900{ }^{\circ} \mathrm{C}$ sample, which contained a mixture of beads and "smashed" beads; all other samples $\left(\mathrm{TiN} / \mathrm{C}-900{ }^{\circ} \mathrm{C}, \mathrm{TiC} / \mathrm{C}-1000{ }^{\circ} \mathrm{C}, \mathrm{TiC} / \mathrm{C}-1100{ }^{\circ} \mathrm{C}, \mathrm{WC} / \mathrm{C}-950{ }^{\circ} \mathrm{C}\right.$ and $\mathrm{WS} / \mathrm{C}-$ $950{ }^{\circ} \mathrm{C}$ ) constituted intact spherical beads. The beads' average diameter was reduced from $0.5 \mathrm{~mm}$ (parent resin) to 0.3 and $0.4 \mathrm{~mm}$ for $\mathrm{W}$ - and Ti-based beads, respectively. This shrinkage can be attributed to (i) sintering of the non-oxide phases and (ii) weight loss due to both the resin carbonisation and the conversion of the oxide to nitride, carbide or sulfide. The shrinkage appeared to be more pronounced in the case of Wbased macrospheres, because of the lower metal content in the metal oxide/resin composite (6 wt.\% for $\mathrm{WO}_{3}$ compared to 25 wt.\% for $\mathrm{TiO}_{2}$, Fig. S2, Supplementary Information), resulting in a higher contraction of the matrix during resin carbonisation. The W-based macrospheres were very hard and difficult to grind in an agate mortar, whereas the Ti-based macrospheres were softer. Nevertheless, all product beads displayed good mechanical stability and could withstand standard laboratory manipulations.

At higher magnifications, an irregular shell was observed by SEM on most of the $\mathrm{WS}_{2} / \mathrm{C}$ beads (Fig. S3, Supplementary Information). Energy-dispersive X-ray spectroscopy (EDX) analysis of the shell and the interior of the beads showed that they were both composed of W and S with C barely detected in the outer shell (Figs. S4 and $\mathrm{S} 5$, Supplementary Information). These results indicate that the materials are $\mathrm{WS}_{2}$ - 
coated $\mathrm{WS}_{2} / \mathrm{C}-950{ }^{\circ} \mathrm{C}$ beads. This observed difference of the carbon content in the beads and the shells could be related to the higher reactivity of $\mathrm{H}_{2} \mathrm{~S}$ with $\mathrm{C}$ present in the outer shell leading to the formation of $\mathrm{CS}_{2}$ gaseous species at the high temperature. ${ }^{22}$ $\mathrm{X}$-ray diffraction (XRD) analysis of the product beads is presented in Fig. 3. The XRD patterns of $\mathrm{TiN} / \mathrm{C}\left(1000{ }^{\circ} \mathrm{C}\right.$ and $\left.1100{ }^{\circ} \mathrm{C}\right)$ and $\mathrm{WS}_{2} / \mathrm{C}-950{ }^{\circ} \mathrm{C}$ bead samples displayed a single crystalline phase (TiN and $\mathrm{WS}_{2}$, respectively). Titanium carbide (TiC) was detected in the $\mathrm{TiC} / \mathrm{C}$ samples prepared at $1000^{\circ} \mathrm{C}$ and $1100{ }^{\circ} \mathrm{C}$, however the intensity of the $\mathrm{TiC}$ peaks was higher in the sample prepared at $1100{ }^{\circ} \mathrm{C}$. Complementary studies by thermogravimetric analysis (TGA) showed that $\mathrm{C}$ was in excess during the carbothermal reduction $\left(\mathrm{TiO}_{2}+3 \mathrm{C} \rightarrow \mathrm{TiC}+2 \mathrm{CO}\right)($ Fig. $\mathrm{S} 2$, Supplementary Information). Since the carbothermal reduction of titanium oxide requires temperatures usually above $1000{ }^{\circ} \mathrm{C},{ }^{23}$ this reduction was not completed even at $1100{ }^{\circ} \mathrm{C}$, as shown by the concomitant presence of $\mathrm{TiO}_{2}$ (rutile) in the sample prepared at this temperature. The WN/C- $900{ }^{\circ} \mathrm{C}$ beads were composed of two different tungsten nitride crystalline phases, $\mathrm{WN}$ and $\mathrm{W}_{2} \mathrm{~N}$. Finally, metal tungsten (W) and tungsten carbide $\left(\mathrm{WC}_{1-\mathrm{x}}\right)$ were observed by $\mathrm{XRD}$ analysis of $\mathrm{WC} / \mathrm{C}-950{ }^{\circ} \mathrm{C}$ beads, indicating the occurrence of metal reduction and carbothermal reduction reactions in this sample.

The preparation of non-oxide TM beads from TM oxide beads obtained after resin oxidation at $600{ }^{\circ} \mathrm{C}$ in air was also tested using the Ti/resin composite. Fig. 4 shows SEM images of the $\mathrm{TiO}_{2}$ sample obtained after the removal of the resin and the corresponding $\mathrm{TiN}$ product. The $\mathrm{TiO}_{2}$ sample contained predominantly broken beads (Fig. 4A), which were inherited by the TiN product (Fig. 4B). XRD analysis indicated a pure TiN phase (Fig. 4C). The result indicates that this approach can also be used to 
prepare non-oxide TM beads provided that intact TM oxide beads are available as a staring material.

\section{Conclusions}

In summary, this study demonstrates the versatility and simplicity of the resin templating method. The method was applied to synthesise a large variety of non-oxide transition metal (TM) macroscopic beads $\left(\mathrm{TiN} / \mathrm{C}-900{ }^{\circ} \mathrm{C}, \mathrm{TiC} / \mathrm{C}-1000{ }^{\circ} \mathrm{C}, \mathrm{TiC} / \mathrm{C}-1100\right.$ ${ }^{\circ} \mathrm{C}, \mathrm{WN} / \mathrm{C}-900{ }^{\circ} \mathrm{C}, \mathrm{WC} / \mathrm{C}-950{ }^{\circ} \mathrm{C}$ and $\mathrm{WS}_{2} / \mathrm{C}-950{ }^{\circ} \mathrm{C}$ ). The process involves heat treatment of TM-loaded ion-exchanged resins in different atmospheres $\left(\mathrm{Ar}, \mathrm{NH}_{3}\right.$ or $\mathrm{H}_{2} \mathrm{~S}$ ). Most of the product beads kept their spherical shape (except for WN/C-900 ${ }^{\circ} \mathrm{C}$ ) and could be manipulated without affecting their macroscopic shape. The macroscopic beads in a non-oxide transition metal form will be interesting for applications in catalysis and where contact with harmful powders and attrition have to be limited while maintaining good flowability for easy handling.

\section{Appendix A. Supplementary data}

Supplementary data associated with this article can be found, in the online version, at

\section{References}

1. L. Tosheva, V. Valtchev, J. Sterte, Silicalite-1 containing microspheres prepared using shape-directing macro-templates, Microporous Mesoporous Mater. 35-36 (2000) 621-629. 
2. L. Tosheva, V. Valtchev, J. Sterte, Amorphous very high surface area silica macrostructures, J. Mater. Chem. 10 (2000) 2330-2336.

3. L. Tosheva, J. Parmentier, V. Valtchev, C. Vix-Guterl, J. Patarin, Carbon spheres prepared from zeolite Beta beads, Carbon 43 (2005) 2474-2480.

4. L. Tosheva, J. Parmentier, S. Saadallah, C. Vix-Guterl, V. Valtchev, J. Patarin, Carbon and $\mathrm{SiC}$ macroscopic beads from ion-exchange resin templates, J. Am. Chem. Soc. 126 (2004) 13624-13625.

5. E. Remy, S. Picart, S. Grandjean, T. Delahaye, N. Herlet, P. Allegri, O. Dugne, R. Podor, N. Clavier, P. Blanchart, A. Ayral, Calcined resin microsphere pelletization (CRMP): A novel process for sintered metallic oxide pellets, J. Eur. Ceram. Soc. 32 (2012) 3199-3209.

6. S. Picart, P. Parant, M. Caisso, E. Remy, H. Mokhtari, I. Jobelin, J. P. Bayle, C. L. Martin, P. Blanchart, A. Ayral, T. Delahaye, Porous metal oxide microspheres from ion exchange resin, Eur. Phys. J. Special Topics 224 (2015) 1675-1687.

7. M. Caisso, F. Lebreton, D. Horlait. S. Picart, P. M. Martin, R. Bès, C. Renard, P. Roussel, D. R. Neuville, K. Dardenne, J. Rothe, T. Delahaye, A. Ayral, Nanostructured gadolinium-doped ceria microsphere synthesis from ion exchange resin: Multi-scale insitu studies of solid solution formation, J. Solid State Chem. 218 (2014) 155-163.

8. M.-L. Wang, C.-H. Wang and W. Wang, Porous macrobeads composed of metal oxide nanocrystallites and with percolated porosity, J. Mater. Chem. 17 (2007) 21332138.

9. K. D. Hristovski, P. K. Westerhoff, J. C. Crittenden, L. W. Olson, Arsenate removal by nanostructured $\mathrm{ZrO}_{2}$ spheres, Environ. Sci. Technol. 42 (2008) 3786-3790. 
10. M.-L. Wang, C.-H. Wang, W. Wang, Preparation of porous $\mathrm{ZrO}_{2} / \mathrm{Al}_{2} \mathrm{O}_{3}$ macrobeads from ion-exchange resin templates, J. Mater. Sci. 46 (2011) 1220-1227.

11. K. Lin, O. I. Lebedev, G. Van Tendeloo, P. A. Jacobs, P. P. Pescarmona, Titanosilicate beads with hierarchical porosity: synthesis and application as epoxidation catalysts, Chem. Eur. J. 16 (2010) 13509-13518.

12. S. Zhang, Y. Jiang, S. Li, X. Xu, K. Lin, Synthesis of bimodal mesoporous titanosilicate beads and their application as green epoxidation catalyst, Appl. Catal. A $490(2015)$ 57-64.

13. D. Cani, P. P. Pescarmona, Macroscopic $\mathrm{TiO}_{2}-\mathrm{SiO}_{2}$ porous beads: Efficient photocatalysts with enhanced reusability for the degradation of pollutants, J. Catal. 311 (2014) 404-411.

14. K. F. Blurton, The preparation of highly dispersed platinum on carbon, Carbon 10 (1972) 305-315.

15. R. D. Holtz, S. Botelho de Oliveira, M. A. Fraga, M. do Carmo Rangel, Synthesis and characterization of polymeric activated carbon-supported vanadium and magnesium catalysts for ethylbenzene dehydrogenation, Appl. Catal. A 350 (2008) 7985.

16. B. Li, W. Dong, Y. Ren, A. Feng, Preparation and characterization of spherical nickel-doped carbonized resin as hydrogenation catalysts: II. Thermal decomposition of resin and preparation of metal-doped catalysts with different nickel loadings, Carbon 45 (2007) 1219-1225.

17. S. Kudo, T. Maki, K. Miura and K. Mae, High porous carbon with $\mathrm{Cu} / \mathrm{ZnO}$ nanoparticles made by the pyrolysis of carbon material as a catalyst for steam reforming of methanol and dimethyl ether, Carbon 48 (2010) 1186-1195. 
18. Q. Gao, N. Liu, S. Wang, Y. Tang, Metal non-oxide nanostructures developed from organic-inorganic hybrids and their catalytic application, Nanoscale 6 (2014) 14106-14120.

19. A.-M. Alexander and J. S. Hargreaves, Alternative catalytic materials: carbides, nitrides, phosphides and amorphous boron alloys, Chem. Soc. Rev. 39 (2010) 43884401.

20. N. Ji, T. Zhang, M. Zheng, A. Wang, H. Wang, X. Wang, J. C. Chen, Direct Catalytic Conversion of Cellulose into Ethylene Glycol Using Nickel-Promoted Tungsten Carbide Catalysts, Angew. Chem. Int. Ed. 47 (2008) 8510-8513.

21. L. E. Toth, Transition Metal Carbides and Nitrides, Academic Press, New York,1971.

22. A. J. Owen, K. W. Sykes, D. J. D. Thomas, P. White, The reactions of carbon with sulphur compounds. Part 2.-The reaction of hydrogen sulphide with various types of carbon, Trans. Faraday Soc. 49 (1953) 1198-1206.

23. M. A. R. Dewan, G. Zhang, O. Ostrovski, Carbothermal reduction of titania in different gas atmospheres, Metall. Mater. Trans. B 40 (2009) 62-69. 


\section{Figure captions}

Fig.1 Schematic illustration of the process used to prepare TM (W or Ti) carbides, sulphides and carbides upon resin carbonisation.

Fig. 2 SEM images of: (A) TiN/C-900 ${ }^{\circ} \mathrm{C}$, (B) TiC/C-1000 ${ }^{\circ} \mathrm{C},(\mathrm{C}) \mathrm{TiC} / \mathrm{C}-1100{ }^{\circ} \mathrm{C}$, (D) $\mathrm{WN} / \mathrm{C}-900{ }^{\circ} \mathrm{C}$, (E) WC/C-950 ${ }^{\circ} \mathrm{C}$ and (F) WS $2 / \mathrm{C}-950{ }^{\circ} \mathrm{C}$ beads.

Fig. 3 XRD patterns of: (left) Ti-based macrospheres and (right) W-based macrospheres. Symbols are: 1 TiN (ICDD 00-038-1420), • Rutile (ICDD 00-021-1276),

* TiC (ICDD 00-032-1383), - $\mathrm{Ti}_{2} \mathrm{O}_{3}$ (ICDD 00-010-0063), + $\mathrm{WS}_{2}$ (ICDD 00-008-0237), $\Delta \mathrm{WC}_{1-\mathrm{x}}(\mathrm{ICDD}$ 00-020-1316), $\circ \mathrm{W}$ (metal) (ICDD 00--004-0806), L WN (ICDD 00025-1256) and $\ddagger \mathrm{W}_{2} \mathrm{~N}$ (ICDD 00-025-1257).

Fig. 4 SEM images of: (A) $\mathrm{TiO}_{2}$ obtained after resin oxidation in air at $600{ }^{\circ} \mathrm{C}$ and (B) the product $\mathrm{TiN}-900^{\circ} \mathrm{C}$ sample, and (C) XRD diffractograms of $\mathrm{TiO}_{2}$ beads and $\mathrm{TiN}-$ $900{ }^{\circ} \mathrm{C}$ beads obtained by nitridation of $\mathrm{TiO}_{2}$ beads. Symbols are:x TiN (ICDD 00-0080237), o Rutile (ICDD 00-021-1276), and I for Anatase (00-021-1272). 
Figure 1

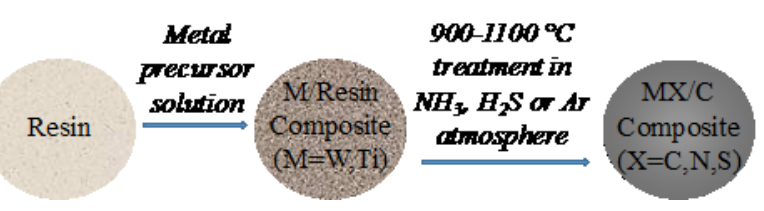


Figure 2

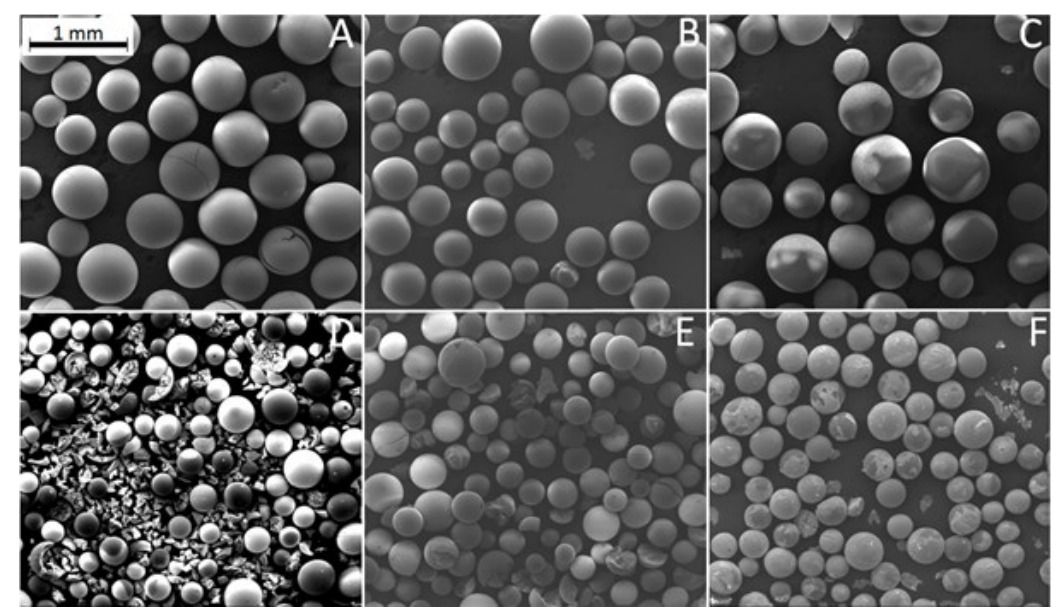


Figure 3

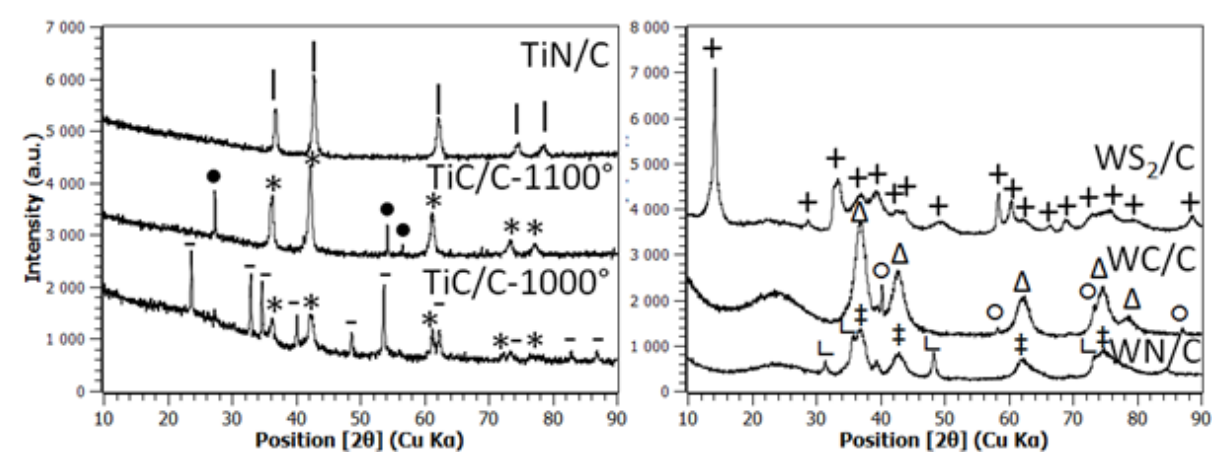


Figure 4
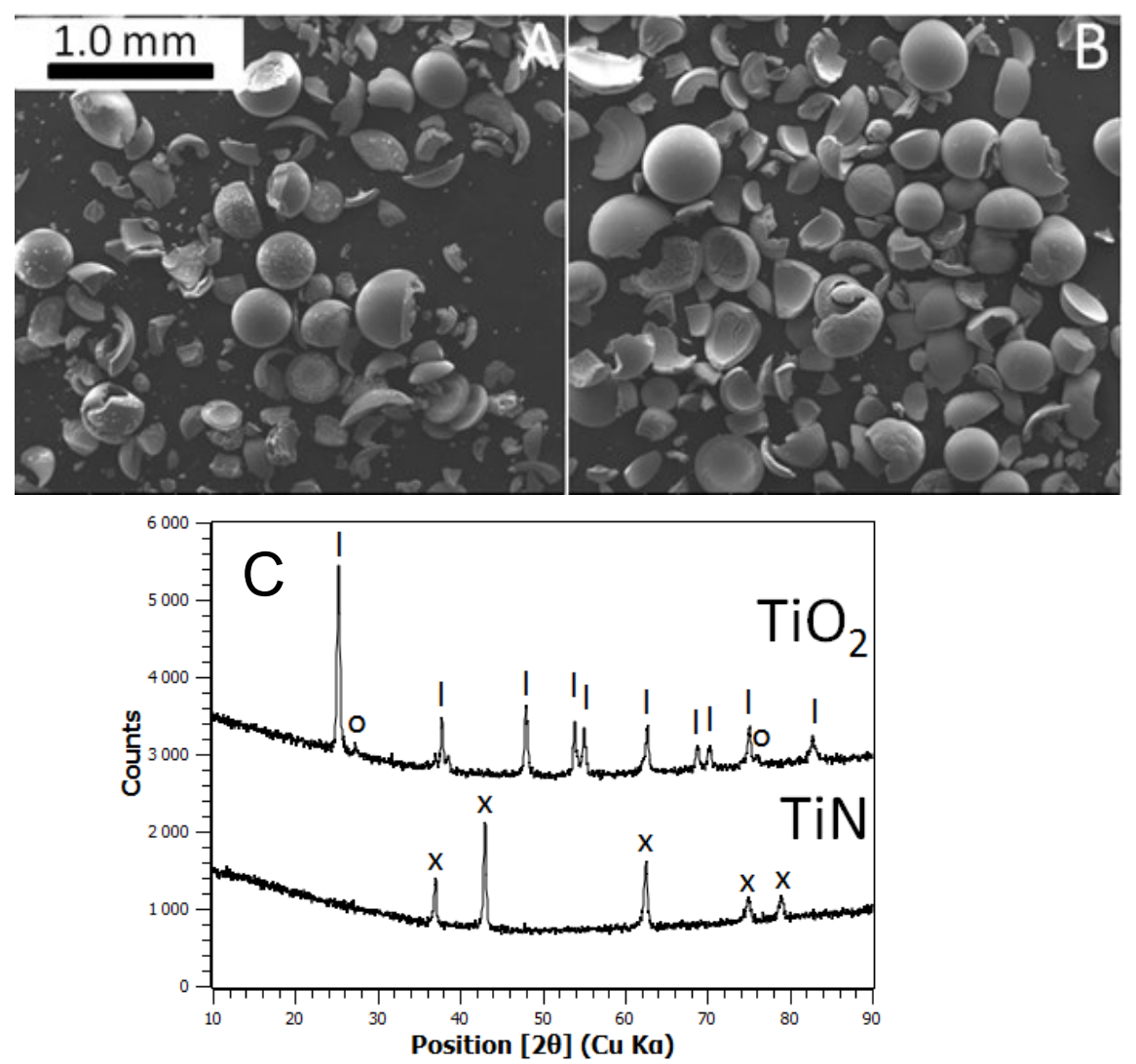